American Journal of Applied Sciences 6 (8): 1515-1520, 2009

ISSN 1546-9239

(C) 2009 Science Publications

\title{
Budget Deficits and Current Account Deficits in the Philippines: A Casual Relationship?
}

\author{
${ }^{1}$ Mosayeb Pahlavani and ${ }^{2}$ Ali Salman Saleh \\ ${ }^{1}$ Department of Economics, Faculty of Economics, University of Sistan and Baluchestan, Iran \\ ${ }^{2}$ School of Economic and Finance, Victoria University, Vic 8001 Australia
}

\begin{abstract}
Problem statement: The problem of budget deficits and current account imbalances has attracted serious consideration from academics and policy-makers in both developed and developing countries. The question is whether such relationships between budget deficits and current account deficits exist in the case of Philippines. Approach: The purpose of this study was to test the validity of the Keynesian proposition and the Ricardian equivalence hypothesis with respect to the direction of causality between budget deficits and current account deficits in the case of the Philippines. Testing procedure was applied to data from that country for the period 1970-2005 to test such relationships. Results: A bi-directional causality between budget deficits and current account deficits was found. This finding was plausible, given the economic crisis in the early 1980s which was associated with economic driven foreign debt in the Marcos era. Conclusion: The results suggested that policy measures to reduce the budget deficit could play an important role in reducing the current account imbalances and vice-versa.
\end{abstract}

Key words: Budget deficits, current account deficits, causality analysis and Philippines

\section{INTRODUCTION}

The issue of budget deficits and current account imbalances has attracted serious attention from academics and policy-makers in both developed and developing countries. There is extensive theoretical and empirical literature examining such relationships in order to explore the possible link between the two deficits and developing countries like the Philippines have not been immune to this problem. It has experienced a series of budget and current account deficits during most of the period between 1970-2003 (Fig. 1). The twin deficits hypothesis argues that an increase in the budget deficit could lead to an increase in current account deficits. Studies by Fleming ${ }^{[10]}$, Mundell $^{[20]}$, Volcker ${ }^{[26]}$, Kearney and Monadjemi ${ }^{[13]}$, Smyth et al. ${ }^{[23]}$ have argued that government deficits cause trade deficits through different channels. For example, in a Mundell-Fleming framework, an increase in the budget deficit could induce upward pressure on interest rates, thus causing capital inflows. This leads to an appreciation of the exchange rate, leading to an increase in the trade deficit. The Keynesian absorption theory argues that an increase in the budget deficit could induce domestic absorption and hence, import expansion, causing a current account deficit.

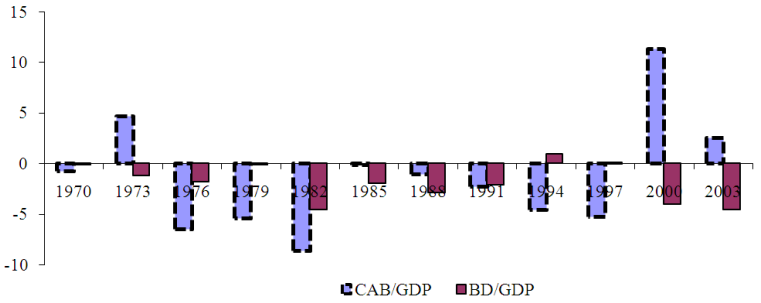

Fig. 1: Budget deficits and current account deficits in Philippines: 1970-200. Source: IMF (various years)

However, in the economic literature there is another view that is the Ricardian Equivalence Hypothesis $(\mathrm{REH})^{[6]}$ which proposes that shifts between taxes and budget deficits does not impact the real interest rate, the quantity of investment, or the current account balance. This means that, REH denies any relationship between the two deficits.

In addition to the above views about the issue of twin deficits, there is another view with supporting empirical studies, which supports a unidirectional causality that runs from current account to budget deficit. This perhaps could be a result of the deterioration in current account leading to lower economic growth and this could increase the budget

Corresponding Author: Ali Salman Saleh, School of Economic and Finance, Victoria University, Vic 8001 Australia Tel: +61 399195271 Fax: +61399194888 
deficit. This view has been empirically supported by Islam $^{[12]}$ for Brazil; Anoruo and Ramchander ${ }^{[3]}$ for five developing economies of Asia; Khalid and Guan ${ }^{[14]}$ for Indonesia and Pakistan. More recently, studies by Alkswani $^{[2]}$ also supported this view in the case of Saudi Arabia. They found that there is a likelihood of this occurring if the government utilizes its fiscal stance to target the current account.

The above arguments show that there are many contrary views on the twin deficits relationship. But empirical analysis of this issue has failed to provide any consensus. Empirical examinations have taken many forms: From single equation Ordinary Least Squares (OLS) models to two stage least squares, from small scale structural models to cointegration and Vector-ErrorCorrection (VEC) models Saleh and Harvie ${ }^{[24]}$. However, studies by ${ }^{[1,7,8,20,22,26]}$, among others, provide support for the Keynesian view that these twin deficits are positively linked and that the budget deficit causes the trade deficit. The empirical evidence on the linkage between current account deficits and budget deficit are mixed.

In contrast to the above, studies by ${ }^{[9,15,19]}$ support the Ricardian equivalence that the budget deficit has no influence on the trade deficits.

The majority of the studies reported above have been focused on the linkages between the twin deficits in the case of developed countries. There have been few empirical studies on the relationship between budget deficits and current account deficits in developing countries, in spite of the importance of such a topic in these countries. One study by Islam ${ }^{[12]}$ which examined the relationship between budget deficits and trade deficits for Brazil from 1973:1 through 1991:4 using the Granger Causality test, found that there is a presence of bilateral causality between trade deficits and budget deficits.

Khalid and Guan ${ }^{[14]}$ utilized cointegration techniques to study the causal relationship between budget and current account deficits. They used a selected sample of five developed countries (US, UK, France, Canada and Australia) and five developing countries (India, Indonesia, Pakistan, Egypt and Mexico) over the period 1950-1994 for developed countries and 1955-1993 for developing countries. It is to be noted that the time series variables involved in their studies are the current account deficit, budget deficit, trade-weighted exchange rate and nominal GNP. They found that there is a causal relationship between budget and current account deficits in four out of five developing countries, while no developed country exercises such a relationship.

More recently, Alkswani ${ }^{[2]}$ studied the relationship between budget deficits and trade deficits in the case of
Saudi Arabia. He uses annual time series data covering the period 1970-1999 and estimates the cointegration regression and the error correction model representation, applies the Johansen cointegration method and tests the existence and the direction of causality. He concludes that there is a long run relationship between the two deficits and the direction of causality runs from the trade deficit to the budget deficit.

Piersanti ${ }^{[21]}$ utilized the Granger-Sims causality technique to examine the relationship between the current account deficit and budget deficits for seventeen OECD countries for the period 1970-1997. They found that there is strong evidence to support the view that current account deficits have been associated with large budget deficits during the 1970-1997 periods in most industrial countries.

Studies by Akbostanci and Tunc ${ }^{[1]}$ used cointegration methodology and the error correction model to study the relationship between the budget deficit and the trade deficit for Turkey during the period of 1987-2001. This study found that the twin deficits hypothesis holds in the case of Turkey.

More, recently, Saleh et al. ${ }^{[23]}$ utilized the ARDL model and the bounds test for cointegration to examine the long run relationship between the twin deficits in Sri Lanka over the period of 1970-2003. Their empirical results support the Keynesian view that there is a long run relationship between the two deficits and the direction of causality runs from the budget deficit to the current account deficit.

This study investigates the relationship between the budget deficit and current account deficits in the Philippines using time series data over the period 19702005. We utilized Toda and Yamamoto's method ${ }^{[27]}$ in order to determine the direction of causality between budget deficits and current account deficits in the Philippines. The advantage of this procedure is that it can be applied irrespective of whether the variables are stationary or contain unit root. Therefore, this procedure reduces the problems which are associated with wrong identification of orders of integration of the series or the existence of potential cointegration between the series.

Public sector deficits in the Philippines: The Philippines experienced volatile economic development since the end of World War II. The Philippines' economy grew consistently and was one of the richest countries in Asia after the war. The average annual growth was 6\% during the period 1965-1980. This was due to the increase in the share of exports in GDP which increased from $12 \%$ in the early 1960 s to more than $20 \%$ in the early $1980 \mathrm{~s}^{[16]}$. However, after this 
sustainable growth during the 1960 and 1970s, the country experienced a major period of political and economic turbulence until the early 1980s. The economic crisis in the early 1980s was associated with economic driven foreign debt in the Marcos era, an unsuccessful expansionary policy between 1979-1982 and political turmoil during the early 1980s, as a result of the assassination of the opposition leader Aquino. The Philippines' economy has experienced serious recession, declining by more than $10 \%$ during 1984-1985. During this crisis the government took some measures including sharp devaluations, a contraction of public investment and high interest rates ${ }^{[16]}$. As a result the economy fell into depression and the real GNP experienced a negative growth rate for the period 1984-1985.

The country experienced a brief stabilization episode during the period 1983-1995 which was followed by recovery during the latter half of the 1980s. The balance of payment became positive, with inflation under control and under the Aquino administration the severe stabilization measures were relaxed and the country underwent economic recovery. In the latter half of the 1980s, GNP growth recovered to 5\%. This recovery did not last for long however. The looming debt and government assumption of the liabilities of the private sector and government sector guaranteed the return to tight fiscal constraints. Given this situation, the economy stagnated again with negative per capita GNP growth from 1991-1993 ${ }^{[16]}$.

However, some progress was made during the Ramos presidency from 1992-1998 in terms of the government budget with a small surplus registered during the period 1994-1997 (Fig. 1). This progress did not last long and the budget went back again into deficit in 1998. During the early 2000s the budget doubled and kept on increasing and in 2003 registered $4.6 \%$ of $\mathrm{GDP}^{[7]}$. In addition, with the devaluation of the Thai bat in 1997, which triggered the Asian currency crisis, the Philippines peso also came under attack. As a result of this crisis, GDP growth in the Philippines fell from $5.2 \%$ in $1997-0.5$ in 1998 . With a smaller pre-crisis expansion of its financial system, the country faced relatively fewer macroeconomic setbacks from the Asian crisis compared to neighboring countries ${ }^{[16]}$.

The Philippine government, under Joseph Estrada's leadership, undertook some economic reforms in order to strengthen regulations with respect to the financial market. Authorities also liberalized the trade sector in order to increase foreign participation in this sector. As a result of that the Philippine economy experienced some signs of a gradual recovery in the following years, with significant growth in the agriculture sector of $6.6 \%$. Strong growth in the agricultural sector and consistent domestic market growth resulted in a reduction in the inflation rate, which averaged $6.6 \%$ in $1999^{[4]}$.

The trade and current account balances grew steadily in the Philippines after the crisis. In 1998, the trade balance rose from $\$ 1.9$ billion to over $\$ 4$ billion in 1999. The current account balance also increased from $\$ 1.3$ billion in 1998 to $\$ 6$ billion in 1999. These surpluses were the result of a strong growth in exports, which accounted for around $20 \%$, especially in sectors such as electronics and components, which registered nearly $60 \%$ of export revenue ${ }^{[4]}$.

The real Gross Domestic Product (GDP) saw significant growth during the post-crisis period. GDP increased by $3.4 \%$ in 1999 (From a $0.6 \%$ fall in 1998) and further growth of $4.4 \%$ was seen in 2000 . However in 2002 , the GDP increased to 4.6 from $3.2 \%$ in $2001^{[5]}$. This was the result of growth in the service sector and good export performance. Stronger growth was seen as well in 2003, as the GDP accounted for $4.5 \%{ }^{[7]}$. These positive outcomes were the result of strong industries and services sectors performance which offset reduced agricultural output growth, as well external factors occurring during this year such as the Iraq War, SARS and other factors.

It should be noted here that by the end of December 2003, the Philippine peso was weakened by more than $110 \%$ vis-à-vis the US dollar since mid-1997. Meanwhile, inflation remained under control, with yearon-year inflation averaging $3.1 \%$ during $2003^{[7]}$. This was associated with some strategic measures taken by the monetary authority, which from early 2002 adopted an inflation-targeting framework for price stability.

While recent statistics of GDP growth have been quite strong, continuing fiscal deficits raise concern among policy makers regarding its sustainability. These deficits grew persistently from $1.9 \%$ of GDP in 1998 to $4.1 \%$ of GDP in 2000 and to 5.3 and $4.6 \%$ of GDP in 2002 and 2003 respectively. These statistics positioned the Philippines as the second largest fiscal deficit amongst the ASEAN countries after Malaysia during the 2000-2001 period $^{[17]}$.

Government expenditure and taxation were less that $10 \%$ of GNP till the 1970s, as the authorities used to take a conservative stance on fiscal activities. Total expenditures were quite small, averaging $5-10 \%$ of national government expenditures. However, national government activity increased to $17 \%$ during the Marcos regime era due to larger capital expenditure and later growing debt service payments. During the 1970s, the Philippines was involved in heavy borrowing from commercial banks, multinational organizations and the USA. By 1976 the Philippines was among the top 100 
recipients of loans from the World Bank. External debt increased in the country from US\$2.3 billion to more than US\$17.2 billion in 1980. During the late 1980s, the ratio of government expenditure rose to $20 \%$ of GNP. Tax revenue was around $12 \%$ of GNP during that time. Chronic government budget deficits were covered by international borrowing during the Marcos era and by domestic borrowing during the Aquino administration. It is important to note here that both approaches have led to a vicious circle of deficits, which require borrowing $^{[25]}$. As can be seen from Fig. 1 the Philippines experienced fiscal deficits most of the years since 1970-2005 except for the years 1994-1996. The fiscal deficit in the Philippines was a major consideration during the early 1990s when it stood at $5.2 \%$ of GNP stand by agreement between manila and the International Monetary Fund (IMF).

Figure 1 shows that the budget deficit in the Philippines as a percentage of GDP has shown larger increases since 1997 (following the Asian financial crisis). These deficits have risen from $1.9 \%$ of GDP in 1998 to $4.1 \%$ of GDP in 2000 and to 5.3 and $4.6 \%$ of GDP in 2002 and 2003 respectively. This growing fiscal deficit was mainly as a result of the deterioration of the national government's revenue effort; weak and inefficient tax collection system. The overall tax effort in the Philippines declined from $17 \%$ of GDP in 1997$12.3 \%$ in $2002^{[17]}$. The government expenditures remained relatively stable at around $19 \%$ of GDP during this study period.

Figure 1 also shows that the country experienced current account deficits most of the years between 1970 and 2005. The deficit averaged around $2.7 \%$ of GDP during the period of 1970-1980. The accumulation of the current deficits continue to increase during the early 1980s due to the oil shock and rise in the world interest rates as well as trade deficit pressure in the country during this period of time. In addition, the deterioration in the trade balance and current deficits during 1990s was the result increased importation of capital goods, which was associated with the surge of FDI inflow into the country. Figure 1 also shows that the external imbalances started to improve after 1997 following a sharp drop in the peso as a result of a sudden reversal of capital flow. It appears that the sharp depreciation in the value of the peso against the US\$ and the yen caused the swing from current account deficit to current account surplus in the post-crisis period.

\section{MATERIALS AND METHODS}

Econometric methodology: As mentioned earlier, the sample period of this study is from 1970-2005. The annual data was obtained from IMF, IFS Yearbook (various years). The variables used in this study are Budget Deficits (BD) and Current Account Deficits (CAD). Both of these variables were measured in terms of their ratios to gross domestic product.

This study used the modified Wald procedure for the causality analysis, which was introduced by Toda and Yamamoto ${ }^{[27]}$. This modified test avoids the problems associated with the ordinary Granger causality procedure by ignoring any possible nonstationary or cointegration between series when testing for causality. The Toda and Yamamoto procedure goes along well with a standard vector autoregressive models in the levels of the variables. This is perhaps in contrast to Granger causality where the first difference has to be taken into account. Therefore, the Toda and Yamamoto approach reduce the risks identified with the possibility of wrongly determining the order of integration of the series and reduces as well the distortion of the size of the tests due to pre-testing ${ }^{[11,18]}$.

Furthermore, the main idea of Toda and Yamamoto $^{[27]}$ is to amend the correct VAR order, K, by the maximal order of integration, $d_{\max }$. After this step, a $\left(\mathrm{k}+\mathrm{d}_{\text {max }}\right)$ th order of VAR is estimated and the coefficients of the last lagged $\mathrm{d}_{\max }$ vector are ignored. The application of this approach emphasizes that the usual test statistics for the Granger causality test has to have the standard asymptotic distribution where valid inference can be achieved. To proceed with this approach, we introduce the current account-budget deficits model in the form of the VAR system as below:

$$
\begin{aligned}
\mathrm{CAD}= & \alpha_{0}+\sum_{\mathrm{i}=1}^{\mathrm{k}} \alpha_{1 \mathrm{i}} \mathrm{CAD}_{\mathrm{t}-\mathrm{i}}+\sum_{\mathrm{j}=\mathrm{k}+1}^{\mathrm{d} \max } \alpha_{2 \mathrm{j}} \mathrm{CAD}_{\mathrm{t}-\mathrm{j}} \\
& +\sum_{\mathrm{i}=1}^{\mathrm{k}} \Phi_{1 \mathrm{i}} \mathrm{BD}_{\mathrm{t}-\mathrm{i}}+\sum_{\mathrm{j}=\mathrm{k}+1}^{\mathrm{d} \max } \Phi_{2 \mathrm{j}} \mathrm{BD}_{\mathrm{t}-\mathrm{j}}+\lambda_{1 \mathrm{t}} \\
\mathrm{BD}= & \beta_{0}+\sum_{\mathrm{i}=1}^{\mathrm{k}} \beta_{1 \mathrm{i}} \mathrm{BD}_{\mathrm{t}-\mathrm{i}}+\sum_{\mathrm{j}=\mathrm{k}+1}^{\mathrm{d} \max } \beta_{2 \mathrm{j}} \mathrm{BD}_{\mathrm{t}-\mathrm{j}} \\
& +\sum_{\mathrm{i}=1}^{\mathrm{k}} \delta_{1 \mathrm{i}} \mathrm{CAD}_{\mathrm{t}-\mathrm{i}}+\sum_{\mathrm{j}=\mathrm{k}+1}^{\mathrm{d} \max } \delta_{2 \mathrm{j}} \mathrm{CAD}_{\mathrm{t}-\mathrm{j}}+\lambda_{2 \mathrm{t}}
\end{aligned}
$$

\section{RESULTS AND DISCUSSION}

Equation 1, Granger causality from BD to CAD implies $\Phi_{1 \mathrm{i}} \neq 0 \forall_{\mathrm{i}}$, similarly in Eq. 2 granger causality from CAD to BD if $\delta_{1 \mathrm{i}} \neq 0 \forall_{\mathrm{i}}$. The model is estimated using seemingly unrelated regression (SUR) ${ }^{[22]}$.

Following Wolde-Rufael ${ }^{[29]}$, the optimal number of lags is selected. Results of the Causality test are shown in Table 1. 
Table 1: Granger non-causality test

\begin{tabular}{llll}
\hline Dependent variable & p-value & $\begin{array}{l}\text { Sum of the lagged } \\
\text { coefficients }\end{array}$ & $\begin{array}{l}\text { Direction of } \\
\text { causality }\end{array}$ \\
\hline From CAD-DB & $0.078^{*}$ & 0.964 & $\mathrm{CAD} \Rightarrow \mathrm{BD}$ \\
From BD-CAD & $0.000^{* * *}$ & 0.084 & $\mathrm{BD} \Rightarrow \mathrm{CAD}$ \\
\hline
\end{tabular}

Sum of the coefficient refers to sum of the valid coefficients in Eq. 2 and 3; *: Significant level at 10\%; **: Significant level at 5\%; ***: Significant at $1 \%$

As shown in Table 1 and as indicated by the significance of the p-values of the modified Wald (MWALD) statistic, there is a bi-directional causality between $\mathrm{BD}$ and $\mathrm{CAD}$ in the Philippine economy. Hence, empirical results indicate that CAD does cause Budget Deficit (BD) in this country as the significance of the $\mathrm{p}$ value of the MWALD statistics is 0.078 . On the other hand $\mathrm{BD}$ also causes $\mathrm{CAD}$ in the Philippine economy, as the significance of the p-value of the MWALD statistics in this case is 0.000 .

\section{CONCLUSION}

This study examines the relationship between the budget deficit and current account deficits in the Philippines using time series data for the period of 1970-2005. We utilized Toda and Yamamoto's procedure in order to determine the direction of causality between budget deficits and current account deficits. The advantage of this procedure is that it can be applied irrespective of whether the variables are stationary or contain unit root. Hence, this method reduces the problems associated with wrong identification of orders of integration of the series or the existence of potential cointegration between the series.

Our empirical results give further support to the Keynesian view that there is a strong link between budget deficits and current account deficits in the Philippines. The results of Toda and Yamamoto's causality analysis supported the existence of bidirectional causality between budget deficits and current account deficits in this country. Therefore, appropriate policy measures to reduce budget deficits could play an important role in reducing the current account deficit and vice-versa.

However, we believe that there are other important factors such as: Improving the terms of trade; coordination of monetary and fiscal policies; a sustained effort to enhance private saving; fiscal consolidation to raise public saving; measures focusing on efficiency improvement as well as the exchange rate, which will complement the budget cut policy. It is also important in the case of the Philippines that even though the country experienced budget deficits during most of the years during 1970-2005, the current account was in surplus after 1998 as a result of an improved trade balance which was driven by the increase in exports and the government policies which attracted FDI and enhanced exports. Hence, we can not treat the budget variable as the only fully controlled policy variable.

This study used the Toda and Yamamoto ${ }^{[27]}$ approach of a one to one relationship but this approach can be extended for future research to include other variables such as exchange rate, private savings and investment, government investment, money stock or interest rates to depict this relationship.

In sum, this study used Toda and Yamamoto's ${ }^{[27]}$ version of non-causality in order to analyze the relationship between budget deficits and current account deficits as compared to other more sophisticated models. Hence, we bring new empirical evidence concerning the twin deficit relationship in a developing country which is consistent with earlier research, the majority of which was in regard to developed countries.

\section{REFERENCES}

1. Akbostanci, E. and G.I. Tunc, 2001. Turkish twin deficits: An error correction model of trade balance. ERC working paper no: 01/06. http://ideas.repec.org/p/met/wpaper/0106.html

2. Alkswani, M.A., 2000. The twin deficits phenomenon in petroleum economy: Evidence from Saudi Arabia. Proceeding of the 7th Annual Conference, Economic Research Forum (ERF), Amman, Jordan, $\quad$ 1-25. http://www.erf.org.eg/CMS/getFile.php?id=750

3. Anoruo, E. and S. Ramchander, 1998. Current account and fiscal deficits: Evidence from five developing economies of Asia. J. Asian Econ., 9: 487-501.

http://ideas.repec.org/a/eee/asieco/v9y1998i3p487501.html

4. Asian Development Bank (ADB), 2000. Philippine economy is likely to grow at a sluggish pace in 2000 .

http://www.adb.org/Documents/News/2000/nr2000 051.asp

5. Asian Development Outlook (ADO), 2003. Economic Trends and Prospects in Developing Asia: Southeast Asia. Asian Development Bank.

6. Barro, Robert J., 1989. The Ricardian approach to budget deficits. J. Econ. Perspect., 3: 37-54.

7. Darrat, A. F., 1988. Have Large Budget Deficits caused Rising Trade Deficits?, Southern Economic Journal, 55: 879-887. http://www.jstor.org/stable/1059523 
8. Egwaikhide, F.O., 1999. Effects of budget deficit on trade balance in Nigeria: A simulation exercise. Afr. Develop. Rev., 11: 265-289. DOI: 10.1111/1467-8268.00011

10. Fleming, J.M., 1962. Domestic financial policies under fixed and under floating exchange rates. International Monetary Fund Staff Papers, 10: 369380 .

11. Giles, D., 1997. Causality between the measured and underground economies in New Zealand, Applied Economics Letters, 4: 63-67. http://web.uvic.ca/econ/wp96-04.pdf.

12. Islam, M.F., 1998. Brazil's twin deficits: An empirical examination. Atlantic Econ. J., 26: 121-128. DOI: $10.1007 / \mathrm{BF} 02299354$

13. Kearney, C. and M. Monadjemi, 1990. Fiscal policy and current account performance: International evidence on the twin deficits. J. Macroecon., 12: 197-220. http://ideas.repec.org/a/eee/jmacro/v12y1990i2p19 7-219.html

14. Khalid, A.M. and T.W. Guan, 1999. Causality tests of budget and current account deficits: Crosscountry comparisons. Empirical Econ., 24: 389-402. http://ideas.repec.org/a/spr/empeco/v24y1999i3p38 9-402.html

15. Kim, K.H., 1995. On the long run determinants of the US trade balance: A comment. J. Post Keynesian Econ., 17: 447-455. http://www.jstor.org/pss/4538454

16. Lim, J. and M.F. Montes, 2000. The structure of employment and structural adjustment in the Philippines. J. Develop. Stud., 36: 149-181. DOI: 10.1080/00220380008422641

17. Manasan, R.G., 2004. Fiscal reform agenda: Getting ready for the bumpy ride ahead. Discussion Paper Series No. 2004-26, Philippines Institute for Development Studies, Philippines. http://ideas.repec.org/p/phd/dpaper/dp_200426.html

18. Mavrotas, G. and R. Kelly. 2001. Old wine in new bottles: testing causality between savings and growth. Manchester School, 69: 97-105. DOI: 10.1111/1467-9957.69.s1.6

19. Miller, S.M. and F.S. Russek, 1989. Are the twin deficits really related? Contemporary Policy, 7: 91-115. http://ideas.repec.org/a/oup/coecpo/v7y1989i4p91115.html
20. Mundell, R.A., 1963. Capital mobility and stabilization policy under fixed and flexible exchange rates. Can. J. Econ. Polit. Sci., 29: 475-485. http://www.sonoma.edu/users/e/eyler/426/mundell 2.pdf

21. Piersanti, G., 2000. Current account dynamics and expected future budget deficits: Some international evidence. J. Int. Money Finance, 19: 255-271. http://ideas.repec.org/a/eee/jimfin/v19y2000i2p255 -271.html

22. Rambaldi, A. N. and Doran, H. E. 1996. Testing for granger non-causality in cointegrated systems made easy, Working papers in Econometrics and Statistics, Department of Econometrics, University of New England, 88: 1-22.

23. Saleh, A.S. et al., 2005. The twin deficits problem in Sri Lanka: An econometric model. South Asia Econ. J., 6: 221-239.

24. Saleh, A.S. and C. Harvie, 2005. The budget deficit and economic performance: A survey. Singapore Econ. Rev., 50: 211-243. DOI: 10.1177/139156140500600204

25. Smyth, D. and Y. Hsing, 1995. In search of an optimal debt ratio for economic growth. Contemporary Econ. Policy, 13: 51-59. DOI: 10.1111/j.1465-7287.1995.tb00731.x

26. Tallman, E. W. and J. A. Rosensweig, 1993. Investigations U.S. Government and Trade Deficits. Economic Review (Federal Reserve Bank of Atlanta), 76: 1-11.

27. Toda, H.Y. and T. Yamamoto, 1995. Statistical inference in vector autoregressions with possibly integrated process. J. Econ., 66: 225-250. http://cat.inist.fr/?aModele $=$ afficheN\&cpsidt $=3520$ 347

28. Volcker, P.A., 1987. Facing Up to the Twin Deficits. In: A Nation in Debt: Economists Debate the Federal Budget Deficit, Fink, R. and J. High (Eds.). University Publications of America, Fredrick, Maryland, pp: 154-161.

29. Wolde-Rafael, Y. 2005. Energy demand and economic growth: the African experience 19 countries, Journal of Policy modeling, 27: 891-903. http://ideas.repec.org/a/eee/jpolmo/v27y2005i8p89 1-903.html 